\title{
A physician and a politician: Dr. Behcet Uz and His Health Policies
}

\section{Bir hekim ve politika adamı: Dr. Behçet Uz ve Sağlık Politikaları}

\author{
Hülya ÖZTÜRK, Ömür ŞAYLIGİL \\ Eskişehir Osmangazi Üniversitesi, Tıp Fakültesi, Tıp Tarihi ve Etik Ana Bilim Dalı, Eskişehir
}

\begin{abstract}
The course of history is changed by the major figures. Even though the reformists and revolutionists are not always appreciated while they are alive, the pacemakers, whose value is appreciated after many years, carve out a niche in history and are recognized by the society. The physicians, surgeons, and politicians influence the society deeply in the historical process. Dr. Behcet Uz, born in 1893, has been greatly admired for his medical skills, his personality promoting common action with the community when he was a mayor, and his revolutionary health care plans executed when he was the Minister of Health. Dr. Uz has been a recognized and an appreciated statesman by many. In this study, Dr. Behcet Uz, who served as the Minister of Health for two terms between 1946 and 1948; and 1954 and 1955, and his efforts in establishing the first and second National Health Care Plans and the Health Bank, which were planned to be executed both in his ministerial terms, were analyzed. Data from the Republic Archives of the Republic of Turkey Prime Ministry, Archives of the Turkish Grand National Assembly, Official Gazettes and private newspapers of the period and face to face interviews performed with the relatives of Dr. Behcet Uz were taken into account.
\end{abstract}

Keywords: Dr. Behcet Uz, health care policies of the Turkish republic period, health care plans, children welfare, preventive medicine

$\ddot{0} \mathbf{z}$

Tarihsel gidişat büyük şahsiyetlerle değişir. Yeniliğe açık devrimci kişilikler yaşadıkları dönemde çok fazla anlaşılamasalar da tarihin gidişatını değiştiren, yıllar sonra değerleri anlaşlan ve örnek alınan kişiler olarak tarih sayfalarında ve insanların zihinlerinde yer edinirler. Tarihsel sürece bakıldığında toplumlarda hekim, cerrah, politikacılar toplumu derinden etkileyen kişilerdir. 1893 doğumlu Dr. Behçet Uz, gerek hekimlik vasıfları, gerek belediye başkanlığı sırasında toplumla ortak hareket eden yapısı, gerekse sağlık bakanı iken ortaya koyduğu devrimci sağlık planları ile büyük takdir toplamış, günümüz açısından herkes tarafından kabul ve takdir edilen bir devlet adamıdır. Bu çalışmada, 1946-1948 yılları ile 1954-1955 yılları arasında iki dönem sağlık bakanlığı yapan Dr. Behçet Uz ve onun her iki bakanlık döneminde de gerçekleştirmeyi planladığı I. ve II. Milli Sağlık Planları ve Sağlık Bankası kurulması çabaları incelenmeye çalışılmıştır. Çalışma sırasında T.C. Başbakanlık Cumhuriyet Arşivi, Türkiye Büyük Millet Meclisi Arşivi, Dönemin Resmi ve Özel gazeteleri ve Dr. Behçet Uz'un yakınları ile gerçekleştirilen yüz yüze görüşmelerin verileri dikkate alınmıştır.

Anahtar kelimeler: Dr. Behçet UZ, Cumhuriyet dönemi sağlık politikaları, sağlık planları, çocuk bakımı, koruyucu sağlık
Alındığı tarih: 09.03.2017
Kabul tarihi: 25.03 .2017
Yazışma adresi: Ass. Hülya Öztürk, Eskișehir Orhan Gazi Üniversitesi Tıp Fakültesi Tıp Tarihi ve Etik Ana Bilim Dalı, 26000, Eskişehir e-mail: hulyaozturk33b@gmail.com

\section{BIOGRAPHY}

Dr. Behcet Uz was born in Buldan district of
Denizli on January 16, 1893 (see Figure 1) ${ }^{(1,2)}$. He attended the elementary school at Hafiz Ibrahim Efendi's School, since it provided a brand new edu- 
cation system. Since Dr. Behcet Uz did not want to go to the madrasah (an Islamic school) after the elementary school, he attended the free boarding school of Izmir High School due to his father Salih Bey's poor financial status ${ }^{(2,3)}$.

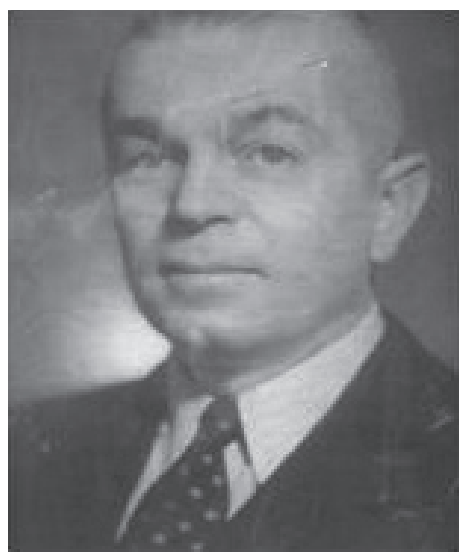

Figure 1. Photograph of Dr. Behcet Uz (takenfrom family).

After completing the high school, Dr. Behcet Uz began to consider an occupation, in which he could be helpful to humans, and which has a line of work on the international platform. Combining his experiences acquired during his father's illness, Dr. Uz was inclined to study medicine and able to register to Tibbiye (Medical School) of Istanbul ${ }^{(1,2)}$ with the help of a letter of recommendation. The prominent figures in the field of health, such as Besim Omer Akalin, Ziya Nuri, Akil Muhtar Ozden, Kadir Rasit, Adnan Adivar are one of the few Tibbiye teachers that had a major impact in the development of Dr. Behcet Uz, as well ${ }^{(2)}$.

After his graduation, Dr. Behcet Uz served as a pediatrician in Istanbul and then in Izmir, for a while. Alongside his career as a physician in Izmir, he served as a mayor for 10 years. Dr. Uz claims his place in history among the legendary mayors. After his mayorship in Izmir, Dr. Uz took another step in politics and served as a Member of Parliament and minister in the Turkish Grand National Assembly. At first, he served as the Minister of Commerce, then as the Minister of Health for two terms ${ }^{(2,4)}$.

Dr. Behcet Uz, passed away in Izmir, in 1986, and he has been commemorated on his death anniversary every year ${ }^{(1)}$. As a symbol of their affection, the citi- zens of Izmir helped erect the statue of Dr. Behcet Uz in the Izmir Culture Park and Fairground, while Dr. Uz was alive ${ }^{(2,4)}$.

\section{INTRODUCTION}

Dr. Behcet Uz was an exceptional person who had been aware of his occupation's effects on human life, and had duly performed his duties. It was clear from the face to face meeting that conducted with his daughter, Mubeccel Versan, in Istanbul-Vanikoy for this study, Dr. Behcet Uz had a compassionate personality alongside his hardworking and diligent nature. Dr. Uz treated patients three days a week for free while he was the superintendent of the Pediatric Clinic at Memleket Hospital, and he also treated patients for 25 kuruş (1 lira equals 100 kuruş) in Fakirler Drug Store when he was first settled in Izmir ${ }^{(1,2)}$.

It is a must to mention briefly Dr. Uz's career before he was appointed to be the Minister of Health. Dr. Behcet Uz became the alderman of Izmir in 1930. Among other posts, Dr. Uz served as the superintendent of the Pediatric Clinic at Memleket Hospital of Izmir, as a college physician, and as deputy chief physician of Aydin Railroad Campaign until $1930^{(1)}$. While serving as the alderman, Dr. Behcet Uz, who systematically put forward the fallacies in the works executed by the municipality at the meetings, was offered the mayorship. Dr. Uz, who took over Izmir in a poor condition, had been elected as a mayor three times in a row for 10 years ${ }^{(1,2)}$.

His first project was to have the Ataturk statue, which had been planned to be erected in Izmir. Dr. Uz had the sculpture erected in Cumhuriyet (Republic) Square, in $1932^{(1-3)}$. Later, he put the expo construction project into effect in a district, where the Hotel Ephesus is located in Izmir, today. The expo project led to the fair project in the course of time ${ }^{(3,4)}$. While many citizens of Izmir, party members, and the community thought that it was only a dream, the foundations of the Culture Park were laid on January 1, 1936. Dr. Behcet Uz who turned the district, consisting of isolated slums and piles of rubble, into the "Culture Park and Fairground," unveiled the Izmir International Fair on September 1, $1936^{(2,4)}$. The 
founder and the President of the Republic of Turkey Mustafa Kemal Ataturk mentioned Dr. Behcet Uz, who was appreciated by the senior statesman, as "our doctor" with a sincere approach in the opening ceremony, in which the President Mustafa Kemal Ataturk, the Prime Minister Ismet Inonu, and Pahlavi the Shah of Iran, participated.

The Behcet Uz Pediatric Hospital, whose foundations were laid in 1937 and opened in 1947, is the first children's hospital of Turkey and has been serving ever since ${ }^{(2,3,5)}$. Dr. Behcet Uz, who served in high-ranking positions in the Society for the Protection of Children, Medical Society, Chamber of Doctors and Tuberculosis Control Society, which was founded by him during his career in Izmir, gained recognition in a short period among the community in Izmir due to his nature of minimizing the bureaucratic difficulties for the community ${ }^{(2,6)}$.

The fair, which was characterized as a dream by many, and the first children's hospital were successfully completed with the earnest and diligent efforts of Dr. Behcet Uz. The desired, but not dared novelties were put at the disposal of the citizens of Izmir.

Undoubtedly, all the work he had done aroused the interest of the statesmen in Ankara. After the private meetings with Ismet Inonu, Dr. Behcet Uz agreed to take a seat in the Turkish Grand National Assembly ${ }^{(1,2)}$. After Dr. Kazim Samanli, the Member of Parliament from Denizli passed away in 1941, Dr. Behcet Uz was elected on behalf of as a new Member of Parliament. Dr. Behcet Uz, who took office upon his certificate of election was sent to the Prime Minister by the Ministry of Interior (see Figure 2), was registered in the file ${ }^{(7)}$ (see Figure 3) exclusive to Turkish Grand National Assembly Members, with the Registration No: 1142, File No: 270, and Envelope No: 18.

According to the Official Gazette No. 5154 and dated July 10, 1942, Dr. Behcet Uz was appointed to be the Minister of Commerce in Sukru Saracoglu's government on July 9, 1942. He retired from the office on March 9, 1943. He worked as a Party Supervisor for CHP Istanbul until he became the Minister of Health in 1946, and kept his interest in functioning of the party ${ }^{(1,2)}$.

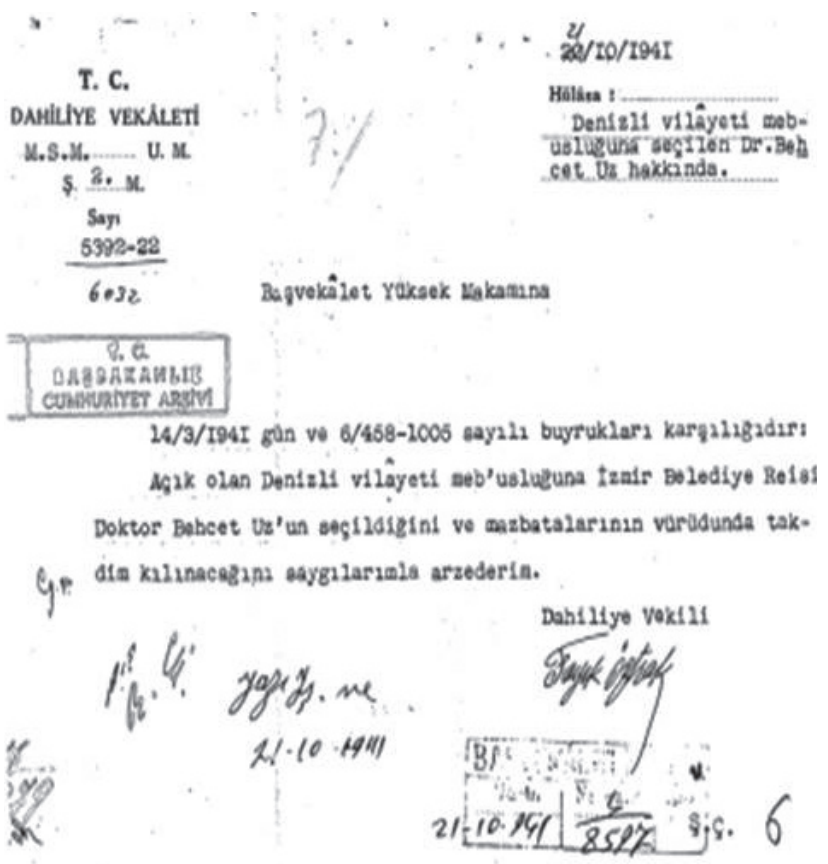

Figure 2. Document sent by Ministry of Interior to the Prime Minister Regarding Dr. Behcet Uz on being Denizli Member of Parliament: Republic Archives of the Prime Ministry.

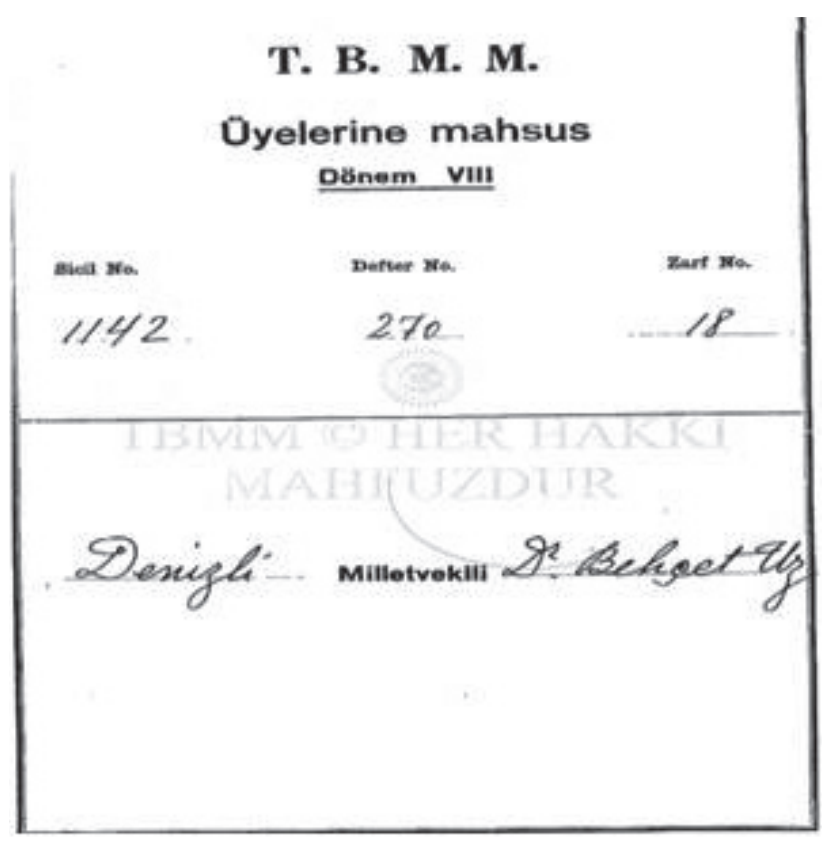

Figure 3. Turkish Grand National Assembly Registry Log: Denizli Member of Parliament.

Dr. Uz as the Minister of Health (1946-1948) and the First Ten-Year Health Plan

Dr. Behcet Uz was elected during the eighth legislative session again ${ }^{(8)}$, and was appointed as the 
Minister of Health in the fifteenth cabinet on August 7, $1946^{(2,9)}$. Thus, in 1946, Dr. Behcet Uz had a chance to provide service in the field of health.

When Dr. Behcet Uz was the Minister of Health, many problems were still present in the country. Dr. Behcet Uz, who primarily evaluated the health care system, witnessed the severity of the diseases like malaria, trachoma, pertussis, cancer, and tuberculosis; lack of health care personnel and multitude of hospital problems, lack of beds, and the necessity for the well-trained health care personnel in order to combat these difficulties ${ }^{(10)}$. Dr. Behcet Uz prepared a ten-year plan also known as "Dr. Behcet Uz Plan," which composed of a variety of factors relating to the health on the conditions of that day, and aimed at spreading the Health Center practices around the country, and announced them to the public in $1946^{(11)}$.

The plan, which was fundamentally put forward to meet the needs of the country and solve the problems relating to health, consisted of six important issues summarized below.

1. Establishing and spreading the preventive medicine organization,

2. Providing the villages and villagers with a health organization,

3. Training the existing and upcoming health personnel in accordance with the existing conditions,

4. Renewing the existing hospitals and health organizations, according to the necessities of the time,

5. Setting up full complement of health facilities in all provinces,

6. Establishing National Health Bank or National Health Insurance Institution and Health Funds in order to deal with these issues most successfully ${ }^{(12) .}$

The purpose of the first article of the plan, the preventive medicine, was to prevent the fellow citizens from getting ill. The key elements of the plan were to establish crucial organizations to inform everyone regarding the child care, protection from various diseases, health education, and training the personnel ${ }^{(12,13)}$.

According to the second, third, and fourth articles of the plan, it was necessary to optimize the existing hospitals and health facilities, according to the neces- sities of the time and technology. As specified in the plan, almost all of the hospitals owned by the private equities and municipalities were in a miserable condition. Therefore, all the private and municipal hospitals shall be transferred to the Minister of Health, and shall be united with the other health facilities of the Ministry ${ }^{(1,2)}$.

According to the fifth article of the plan, new facilities and health centers, which would meet all kinds of health and social needs in terms of the personnel and organization similar to a Medical Faculty, were going to be established based on the seven regions of the country. Considering the hospitals owned by the public, private equities, municipalities, minoritiesinstitutions and individuals; the number of beds were 16364 in that period. 7500 of them were in Istanbul. According to the statistics, 8.5 beds were available for ten thousand people. This number should have been increased to $24^{(14,15)}$.

In order for the health plan to be implemented, 623 million Turkish liras were required. In this case, 50-55 million Turkish liras were going to be spent. There weren't any financial resources other than those of the government in order to implement this plan. The government's resources were not favorable in these circumstances. Therefore, the health facilities must have been established with the help of insurance premium revenues by forming health insurance in order to eliminate the financial gap ${ }^{(15)}$.

The reason why the "Health Insurance Funds" were established was to provide the insurance holders with treatment when they are ill, lose their payments, and to pay maternity benefit and fund to the pregnant women with the help of subsidies. Providing subsidy in case of death as part of insurance was also in to do list ${ }^{(16)}$.

According to the second-page article of Aksam Newspaper dated August 13, 1947, Health Insurance Draft Law was to be discussed and presented to the assembly within two weeks. When the draft was presented to the Assembly, it received great compliments by the members ${ }^{(14,17)}$.

The Health Insurance System was implemented in the United States of America (USA) in the same years, and millions of people benefited from the 
system. Especially the workers in the USA, which had been focusing on this issue with the intention of protecting its citizens against the hazardous industry since 1921, participated in this system. This system was in such a big demand that some of the employers were able to provide free treatment depending on their financial statuses. USA was able to provide their citizens with treatment by installments in 31 out of 48 states in six years.

The Health Plan, which turned into a draft law in about a year and a half, was accepted by the Council of Ministers and four commissions of Turkish Grand National Assembly; however, it did not become a law due to the government changes. The draft was withdrawn by the new Minister of Health, Dr. Kemal Beyazit ${ }^{(2,11)}$.

The First Ten-Year Health Plan had caused a stir in the community and it was neither put into action legally during Dr. Behcet Uz's term, nor after him. No concrete step was taken until 1948, even after Dr. Behcet Uz became the Minister of Health. Not even a year passed, the plan, which was once highly praised when presented to the assembly as a draft, was criticized for being unrealistic ${ }^{(11,18)}$. Even though it was not successful, it can be stated that the plan, which was put forward with the intention of providing the services, which are now carried out by today's health care centers, was ahead of their time in terms of politics in 1947.

\section{Other Health Care Services Provided by Dr. Behcet Uz (1946-1948)}

Dr. Behcet Uz supported establishing faculties and hospitals countrywide. He announced that the dispensaries would be built with the intention of increasing the number of beds ${ }^{(19)}$, along with establishing a big worker's hospital in Istanbul ${ }^{(20)}$.

Dr. Behcet Uz himself took part in establishing health institutions such as hospitals and sanatoriums nationwide. He expressed that "these missions will speed up" in the opening ceremony of the new pavilion of the Heybeliada Sanatorium ${ }^{(20,21)}$. The nationwide contagious diseases of the period, such as tuberculosis, malaria, plague, pertussis, and cholera were eliminated with the implementation of the most recent vaccinations ${ }^{(22)}$.

Dr. Behcet Uz, who put major importance on nationwide tours between 1946 and 1948, tried to follow the developing conditions in the country in person. Izmir, Manisa, Aydin, Trabzon, Zonguldak, Heybeliada, Istanbul, East and Southeastern Anatolia were especially inspected by the Ministry ${ }^{(23)}$. The southern regions, where malaria and trachoma were reported, were continually kept in under control in order to facilitate leading a quality and healthy life (24) Dr. Behcet Uz himself participated in opening ceremonies of the hospitals in this region. Dr. Behcet $\mathrm{Uz}$ kept in touch with abroad as well, and he was always a close relationship, especially with USA. He was invited by the Rockefeller health organizations in Britain and in USA in around 1948. He continually followed the success of USA regarding the Health Funds and this accomplishment was a source of inspiration when he was implementing his own plan ${ }^{(25)}$.

Dr. Behcet Uz's Years in the Democratic Party and His Projects as the Minister of Health

Together with the changes made in the elections of 1950 , the ruling party had been the Democratic Party for a long while. The health system implemented in the rural area before the Democratic Party was not successful. The members of the Democratic Party , who were stating that the "Examination and Treatment House" system implemented in the field of health in the country, must have been abandoned, and were of the opinion that it was necessary to spread the "Health Centers" (11,26-28).

After the elections of May 2, 1954, the new legislative session of Turkey started. In the twenty-first term Democratic Party cabinet, which won the elections, Dr. Behcet Uz became the Minister of Health. Dr. Uz initiated his second term as the Minister of Health by studying the developments that took place after him. Dr. Behcet Uz announced his project titled "Researches on National Health Program and Health Bank" on December 8, $1954^{(2,28,29)}$. The project was a follow-up for his first National Health Plan in order for him to carry out the health program this time.

Turkey's health care conditions and aims in the Health Program of 1954 were announced as follows:

1. Establishing a board of health in the districts 
in the form of an organization in order to protect and control the health of the towns and villages, where approximately $85 \%$ of the population lives, and take the necessary measures quickly as a matter of urgency to decrease the diseases and deaths. This organization shall be able to operate both as a protective and curative mission within the health centers.

2. The provincial hospitals shall be equipped with modern equipment. The number of beds shall be increased so that they can catch up progress, technic, and at the same time satisfy the current requirements.

3. With respect to the wideness of the country, the national population is small and sparse. Fully equipped health districts, which will cover all the regions, shall be established.

4. A protective health organization against the contagious diseases, which sicken or kill the population groups in a mass, shall be made ready for activity in every part of the country.

5. The infant formulas imported from abroad both cost a lot and had negative outcomes. The child foods shall be produced at home for cheaper prices with beneficial nutrients and their producers shall be subsidized.

6. The hot springs and healing waters in Turkey, which are not adequately benefited for centuries , shall be offered to the community as modern aqua therapy facilities ${ }^{(29,30)}$.

The preliminary preparations for the second health plan, which was planned to be completed in ten years, were achieved. Annual statistics on the number of deaths, childbirths and contagious diseases in the country were prepared ${ }^{(31)}$.

Especially the preventive medicine was given importance in the program and thus it was aimed to decrease the load of the hospitals. The health facilities shall be established based on the district and thus when providing treatment, the congestion in several major cities shall be prevented. The services, which were addressed in seven regions in the previous health plan, shall be increased to sixteen regions according to "District Board of Health" system. These regions were thought to be Ankara, Antalya, Bursa, Diyarbakir, Elazig, Erzurum, Eskisehir, Istanbul, Izmir, Konya, Sakarya, Samsun, Seyhan,
Sivas, Trabzon, and Van ${ }^{(30-32)}$.

The purposes listed under the title of "District Board of Health" in the plan was the rearrangement of the "health center" operations in terms of enforcement. The district board of health consisted of the public health and preventive medicine services of the central district and the boroughs and villages which were parts of this central district. It was planned that the professional, technical, and administrative personnel alongside the governmental and municipal doctors would be employed by the district board of health, and one of the governmental doctors was going to be the chief of medicine. The district board of health was to function in districts where health centers were located. The District Board of Health, which was going to perform in the suitable parts of the hospitals was going to be able to coordinate with the hospital administrations.

The preventive medicine services were the primary services among those provided by the District Board of Health. Keeping the statistics for births, deaths, and patients, protecting mother's and children's health, fighting against the social diseases such as tuberculosis, malaria, and pox could be considered as the services among the preventive medicine. Ensuring patient admission to the hospitals, registering the patients to the hospitals, performing polyclinic services, determining the examination and treatment costs and assisting the community when providing these services could be considered among the Curative Medical Services provided by the District Board of Health ${ }^{(30-32)}$.

Dr. Behcet Uz brought up the establishment of the Health Bank again in 1954, in order to provide the services planned to be executed in accordance with the plan as mentioned above. Regarding the establishment of the Health Bank, the objectives included insuring the community for a fee, covering treatment costs of those who did not have health insurance and could not cover their own expenses with the help of the special administration's budget, financing the health expenses by establishing the Health Bank, monitoring the production of the medical goods such as medications, serums and vaccinations, and establishing industrial institutions which could provide the infant food, such 
as milk and formula. Collecting taxes on alcoholic beverages was also part of the plan ${ }^{(33,34)}$.

Dr. Behcet Uz hoped to execute the plan, which was not accomplished when he was a member of the Republican Party When Dr. Uz became a member of Democratic Party; the president of Democratic Party, Adnan Menderes promised him, saying "perhaps, you may be able to pass the plan that you could not." Even though the Health Plan had been favored and as well as promoted by the whole cabinet of Democratic Party, it was hindered by the investigation committee of the assembly and was not implemented. Dr. Behcet $\mathrm{Uz}$, who was promised to be able to implement the plan, filled with sorrow from the incident and resigned from the Minister of Health soon after, saying "the projects that could have been beneficial for the country are prevented by unreasonable conditions and the nation suffers from it" ${ }^{2,5)}$.

\section{Other Health Care Services Provided by Dr. Behcet Uz (1954-1955)}

During the time Behcet Uz was assigned in the Democratic Party, he put a lot of importance on opening the hospitals. It was planned to build a Worker's Hospital with 560 beds on Istanbul Samatya Street; as well as a Tradesmen Hospital, which was planned to be built around that time. Increasing the number of beds in the country by building worker's hospitals in Istanbul, Izmir, Bursa, Samsun and Eskisehir was also considered ${ }^{(33,34)}$.

Dr. Behcet Uz, who increased the measures in order to solve the problems regarding the hospitals, had the "Hospital Regulations" formed, and helped it to obtain the Council of Ministers' approval. Measures, which would ensure that the hospitals would operate better and prevent the waste of drugs, food, and equipment, were taken within these regulations ${ }^{(35,36)}$.

The scarcity of medications, primarily scarcity of the antibiotics, raised major concerns in the country in 1954. The Minister of Health raised special funds and announced that " 2.5 million Turkish liras worth drug funds will be allocated" in order to be able to solve the problem. It was aimed to open medicine cabinets where there were no pharmacists by means of the Medicine Cabinet Regulations ${ }^{(37-40)}$.
Nineteen fifties, and sixties were significant periods for the Turkish Ministry of Health in the fight against tuberculosis, malaria, trachoma and sexually transmitted diseases ${ }^{(11,40,41)}$. The fight against the contagious diseases was based upon healing the patients and then protecting the community from contracting these diseases by means of preventive medicine applications within the concept of a plan.

\section{Coup D'état of May 27, 1960 and Days in Yassiada}

A military coup took place in Turkey on May 27, 1960. Thus, the Turkish Armed Forces annulled the Democratic Party government and prohibited other political parties ${ }^{(42-44)}$.

Dr. Behcet Uz, who was a Democratic Party member of parliament, had been arrested with the second order of arrest ${ }^{(45)}$, and was sentenced to four and a half years in prison following the trials. Later, Dr. Behcet Uz, who was sent to Kayseri prison, was given early release from prison with an amnesty.

\section{CONCLUSIONS}

The new Turkish Republic was officially founded in 1923. The state, which was in a war since the second half of the nineteenth century, had many health issues. The Model for State Doctors, which was applied in the late Ottoman Empire, was aimed to be maintained in the new Republic, as well.

Dr. Behcet Uz, who meticulously analyzed all the studies conducted in the past, attributed the reason why the state was in such condition in health explaining that the Turkish Republic was a novel Republic at the time, financial shortage arising from the second World War and that the country did not follow a specific plan and protocol in the missions conducted up until then. Therefore, Dr. Uz scheduled his plans that would be implemented in both his ministerial terms and proceeded in accordance with his plans.

While Dr. Uz pointed out the importance of establishing health centers within a plan, implementing preventive medicine applications, and eliminating the contagious diseases; he solved the health problems dating back to the previous terms. He also interfered 
with the financial issues and avoided the mistakes made by his predecessors. Even though both of the prepared plans had been approved in the assembly, they were not implemented since they did not receive sufficient support from the state.

While Dr. Behcet Uz conducted meticulous studies when preparing Health Care Plans, he put in efforts implementing the health care procedures similar to those of other countries, particularly the USA. These two statements were significant since they signify Dr. Behcet Uz's objectives as the Minister of Health, which were innovative and in favor of the developments in the world.

The innovations aimed at both plans are today's trending values. Dr. Behcet Uz, who tried to prepare and implement these plans in a period when there were a variety of material and moral problems after long work hours, is a foresighted, brave and decisive statesman who has been remembered and mentioned today. The studies put forward by him have been the reason why Dr. Behcet Uz is respected and appreciated.

"Dr. Behcet Uz, the Man Who Enabled Izmir to Breathe," led an honorable life and dedicated his whole life to his citizens, society, and his beautiful Izmir. With his opinions and actions that affected his period, Dr. Uz has been one of the primary figures that changed the course of Turkish Republic's history.

The important steps, which were taken in forming the health policies in this period, primarily the community health care, also contributed to the approaches and health policies within the period after his post.

Dr. Behcet Uz was not only a physician but also a societal leader who took an important role in the community. He has been among the people that can be taken as an example by the young physicians with his revolutionist nature that resisted against the false applications and duly performed the duties.

\section{Acknowledgments}

The authors would like to thank the daughter of Dr. Behcet Uz, Mubeccel Uz Versan and his son Ethem Uz for sharing Dr. Uz's relationships in real life for this study, the president of the Izmir Chamber of Commerce Business Committee Sancar Maruflu and his son-in-law Prof. Dr. Munci Kalayoglu.

\section{Declaration of Conflicting Interests}

The author(s) declare no potential conflicts of interest with respect to the research, authorship, and/ or publication of this article.

\section{Funding}

The author(s) received no financial support for the research, authorship, and/or publication of this article.

\section{REFERENCES}

1. Güzel Izmir Dergisi. Dr. Behçet Uz. September 24, 1999; Issue no: 5, Guzel Izmır Dergisi. August 26, 2000; Issue no: 8.

2. Uz B. Atatürk'ün İzmir'i, Bir Kentin Yeniden Doğuşu, In.L.Ece Sakar (ed). [Izmir of Ataturk, Rebirth of a City], Türkiye İş Bankası Yayınları, Istanbul, 2007. p.1-178.

3. Akyüz Levi EA. Dr. Behçet Uz Çocuk Hastanesi Cephe Renovasyonu ve Çevre Düzenlemesi [Dr. Behçet Uz Children's Hospital Facade Renovation and Landscaping]. Yapı Dergisi 2004; Issue no. 267: 710-5.

4. Dr. Behcet Uz Archive Documents belonging to Sancar Maruflu.

5. Diker HI. Dr. Behçet Uz Çocuk Hastanesi Tarihi ve 19471954 Yılları Faaliyetleri [Dr. Behcet Uz Children's Hospital History and Activities of 1947-1954 years], Gayret Basımevi, İzmir, 1954. p. 13-14.

6. Izmir Eski Belediye Reisi, Ticaret ve Sağlık Vekillerinden Dr. Behçet Uz'un Biyografisi. [Biography of Dr. Behçet Uz who is former Mayor of Izmir, Chairman of Trade and Health]. İzmir. 1967, p.1-2.

7. Güneş I. Parlamento Tarihi [History of Parliament], $2^{\text {nd }}$ Volume, Türkiye Büyük Millet Meclisi Vakfı, Ankara, 1999. p.201.

8. Türkiye Büyük Millet Meclisi Albümü 1920-2010. $1^{\text {st }}$ Volume. 1920-1950, Türkiye Büyük Millet Meclisi Basın Halkla İlişkiler Yayınları, 2010.

9. Dirican R. Dr. Behçet Uz ve Ulusal Sağlık Planı [Dr. Behçet Uz and His National Health Plan]. Toplum ve Hekim 2001; Volume 16, Issue no.6: 465,466,467.

10. Ulus Newspaper. April 13, 1947, p.2.

11. Aydın E. Türkiye'de Sağlık Teşkilatlanması Tarihi [History of the Organization of Health in Turkey]. Naturel, Ankara, 2002. p.33-49.

12. Aksam Newspaper. July 20, 1947, p.3; Aksam Newspaper. September 11,1947, p.3.

13. Türkiye Büyük Millet Meclisi Tutanak Dergisi [Report Journal of Turkish Grand National Assembly]. 1947. 3;54775.D.8.

14. Cumhuriyet Newspaper. October 26, 1946 p.3; Cumhuriyet Newspaper. January 3, 1948, p. 1.

15. Aksam Newspaper. May 26, 1947, p.3.

16. Türkiye Büyük Millet Meclisi Tutanak Dergisi [Report Journal of Turkish Grand National Assembly], 1948. 8;71143.D.8.

17. Aksam Newspaper. August 13, 1947, p.2.

18. Aksam Newspaper. July 2, 1947, p.1.

19. Aksam Newspaper. January 3, 1947, p.2.

20. Aksam Newspaper. January 4, 1947, p.1. 
21. Cumhuriyet Newspaper. September 29, 1946, p.2.

22. Aksam Newspaper. May 6, 1947, p.4; Aksam Newspaper. February 3, 1948, p.4.

23. Ulus Newspaper. July 22, 1947, p. 9; Ulus Newspaper. July 31, 1947, p.2.

24. Aksam Newspaper. February 12, 1947, p.2.

25. Cumhuriyet Newspaper. May 16, 1950, p.1.

26. Türkiye Büyük Millet Meclisi Zabıt Cerideleri, 1954.

27. Aksam Newspaper. January 27, 1955, p.4.

28. Demirel H. Çok Partili Siyasi Hayata Geçerken Sağlık Politikaları [Multi-Party Political Life in passing Health Policy]. Sağlık Dergisi, e-magazine, Sağlık Düşüncesi ve Tıp Kültürü, Issue no: 20, p.1.

29. Akdağ R. Nereden Nereye, Türkiye Sağlıkta Dönüşüm Program1 [From where to where, Turkey Health Transformation Program]. Ankara, November 2002-June 2007.

30. Resmi Gazete. July 7, 1955, Issue no: 9048, p.12289-95.

31. Aksam Newspaper. January 6, 1955, p.1; Aksam Newspaper. January 23, 1955, p.2; Aksam Newspaper. January 31, 1955 , p.1.

32. Aksam Newspaper. June 19, 1954, p.3.

33. Resmi Gazete. April 4, 1955, Issue no:8972, p.11466.

34. Aksam Newspaper. January 6, 1955, p.1; Aksam Newspaper.
April 11-12, 1955, p.1-3.

35. Aksam Newspaper. June 18, 1954, p.3; Aksam Newspaper. March 3, 1955, p.3.

36. Resmi Gazete. Kararname. April 4, 1955, Issue no: 8972, p.11465-11495.

37. Türkiye Büyük Millet Meclisi Zabıt Cerideleri. May 13, $1955,1^{\text {st }}$ Volume, Issue no: 75, p.226.

38. Hurriyet Newspaper. May 28, 1954, p.7.

39. Resmi Gazete. March 3, 1955, p.11269-70.

40. Hurriyet Newspaper. June 1, 1954, p.1; Hurriyet Newspaper. May 10, 1955, p.1.

41. Aksam Newspaper. April 27, 1955, p.3.

42. Abadan N Ü. Bürokrasi [Bureaucracy]. AÜSBF Yayınları, Ankara, 1959. p.73-192.

43. Turgut H. Menderes, Zorlu, Polatkan'in Yaptırılmayan Savunmaları [Not Built Defenses of Menderes, Zorlu and Polatkan]. ABC Ajansı Yayınları, Istanbul, 1988. p.22,3236.

44. Göksu S. Darbeler, Demirkıratlar ve 27 Mayıs [Beats, Demirkırats and 27 May]. Anahtar Kitaplar Yayınları, Istanbul, 1993. p.81-90.

45. Republic Archives of the Prime Ministry, document numbered 030-01-45-272-1. 